\title{
Homo sapiens: The Superspreader of Plant Viral Diseases
}

\author{
Buddhini Ranawaka, Satomi Hayashi *, Peter M. Waterhouse and Felipe F. de Felippes *
}

Centre for Agriculture and the Bioeconomy, Institute for Future Environments, Queensland University of Technology (QUT), 2 George Street, Brisbane, QLD 4000, Australia; ra.ranawaka@qut.edu.au (B.R.); peter.waterhouse@qut.edu.au (P.M.W.)

* Correspondence: satomi.hayashi@qut.edu.au (S.H.); felipe.felippes@qut.edu.au (F.F.d.F.)

Academic Editors: Michael Goodin and Jeanmarie Verchot

Received: 20 November 2020; Accepted: 15 December 2020; Published: 17 December 2020

\begin{abstract}
Plant viruses are commonly vectored by flying or crawling animals, such as aphids and beetles, and cause serious losses in major agricultural and horticultural crops. Controlling virus spread is often achieved by minimizing a crop's exposure to the vector, or by reducing vector numbers with compounds such as insecticides. A major, but less obvious, factor not controlled by these measures is Homo sapiens. Here, we discuss the inconvenient truth of how humans have become superspreaders of plant viruses on both a local and a global scale.
\end{abstract}

Keywords: plant viruses; viral vectors; plant diseases; virus spread

\section{Introduction}

In the year 2020, the world has seen the fast and perverse spread of SARS-CoV-2, which has led to a shutdown of our societies and the loss of 1.3 million human lives worldwide so far [1]. Although unfamiliar to most people, plants are also susceptible to infection by wide range of viruses. Furthermore, damages caused by plant viruses on human lives can be as strong, or even more serious than those caused by their animal counterparts. Throughout history, the outbreak of diseases caused by plant viruses have been major contributors to chronic food insecurity [2], a scenario that tends to worsen with our ever-growing population.

Plant viruses constitute a major cause of plant diseases with an estimated economic impact of more than USD 30 billion annually [3]. Some viruses can wipe out entire plantations, resulting in $100 \%$ yield loss $[4,5]$ and, subsequently affecting the revenue of farmers, increasing the price of food, and in more extreme cases, its availability to the market. Globally, the most destructive plant viruses are identified to be members of begomoviruses, tospoviruses and potyviruses. Significant epidemics caused by these viruses include not only those affecting economically important plants, but also staple food crops such as cassava, maize, rice and banana. Therefore, in addition to causing damage to farmers' and countries' economies, such plant disease epidemics can also lead to the starvation of a significant portion of the world's population who depend on these plants for their subsistence $[3,6]$.

While the spread of animal viruses is most often associated with direct contact or proximity to infected individuals, plant viruses are transmitted through wounds on the plant or via a vector, most often insects, fungi and nematodes that feed or infect the plant [3]. Although these vectors have often been the major target for controlling the spread of plant viral diseases, it is apparent that human activities also play a major role in the dissemination of plant viruses (Table 1). Man has distributed most of the cultivated plants around the world by removing them from their centre of domestication. As such, humans are greatly responsible for the novel encounters between plants and their pests [7]. Since many plant viruses have a broad range of hosts and vectors [8], introduction of crops to a 
new area can enable indigenous viruses from native plants to spread to the crops, and vice versa [3]. Moreover, modern agricultural systems, such as monocultures, have intensified and altered agricultural practices. Continuous cropping patterns encourage the accumulation of viruses and proliferation of their vectors in the field, leading to pandemics. 
Table 1. Human intervention in the spread of plant viruses.

\begin{tabular}{|c|c|c|c|c|}
\hline Virus & Genus & Vector & Host & Human Intervention \\
\hline Banana bunchy top virus (BBTV) & Babuvirus & Aphids & $\begin{array}{l}\text { Banana, plantain, abaca and other plants in } \\
\text { family Musaceae }\end{array}$ & $\begin{array}{l}\text { Trade of vegetative planting and tissue culture } \\
\text { material [9] }\end{array}$ \\
\hline Banana streak virus (BSV) & Badnavirus & Mealybugs & Banana, Heliconia & $\begin{array}{l}\text { Trade of vegetative planting and tissue culture } \\
\text { material [10] }\end{array}$ \\
\hline African cassava mosaic virus (ACMV) & Begomovirus & Whitefly & Cassava, castor bean & $\begin{array}{l}\text { Exchange of virus infected plant material. Trade of } \\
\text { infected seeds and plant material [11] }\end{array}$ \\
\hline Tomato yellow leaf curl virus (TYLCV) & Begomovirus & Whitefly & French bean, Solanaceous plants & Accidental movement of insect vector [12] \\
\hline Cauliflower mosaic virus (CaMV) & Caulimovirus & Aphids & $\begin{array}{l}\text { Cauliflower, Chinese cabbage, brussels } \\
\text { sprout, turnip }\end{array}$ & $\begin{array}{l}\text { Virus contaminated machinery, equipment and } \\
\text { workers [13].Trade of infected plant material [14] }\end{array}$ \\
\hline Cucumber mosaic virus (CMV) & Cucumovirus & Aphids & Soybean, tobacco, pepper & Trade of infected seeds and plant material [15] \\
\hline Tobacco necrosis virus (TNV) & Necrovirus & Olpidium brassicae & $\begin{array}{l}\text { French bean, cowpea, mung bean, melon, } \\
\text { tulip, tobacco, cucumber }\end{array}$ & $\begin{array}{l}\text { Virus contaminated machinery, equipment and } \\
\text { workers [16] }\end{array}$ \\
\hline Plum pox virus (PPV) & Potyvirus & Aphids & Apricots, peaches, plums, almonds & $\begin{array}{l}\text { Grafting, budding, and transplanting of infected } \\
\text { plant material [17] }\end{array}$ \\
\hline Potato virus Y (PVY) & Potyvirus & Aphids & Potato, tomato, capsicum, tobacco & $\begin{array}{l}\text { Virus contaminated machinery, equipment and } \\
\text { workers [18]. Trade of infected plant material [19] }\end{array}$ \\
\hline Maize dwarf mosaic virus (MDMV) & Potyvirus & Aphids & Maize, sugarcane, sorghum & Trade of infected plant material [20] \\
\hline $\begin{array}{l}\text { Sweet potato feathery mottle } \\
\text { virus (SPFMV) }\end{array}$ & Potyvirus & Aphids & Sweet potato, wild Ipomoea sp. Nicotiana sp. & $\begin{array}{l}\text { Trade of infected tubers and cuttings, grafting, and } \\
\text { mechanical inoculation [21] }\end{array}$ \\
\hline Zucchini yellow mosaic virus (ZYMV) & Potyvirus & Aphids & Cucumber, pumpkin, rockmelon, zucchini & $\begin{array}{l}\text { Virus contaminated machinery, equipment and } \\
\text { workers [22] }\end{array}$ \\
\hline Sugarcane mosaic virus (SCMV) & Potyvirus & Aphids & Sugarcane and Poaceae plants & Trade of infected plant material [23] \\
\hline Rice yellow mottle virus (RYMV) & Sobemovirus & $\begin{array}{l}\text { Adult beetles in family } \\
\text { Chrysomelidae, } \\
\text { Grasshoppers }\end{array}$ & Rice & $\begin{array}{l}\text { Virus contaminated sickles, hands and crop } \\
\text { residues. Tight contact between plants during } \\
\text { planting }[24,25]\end{array}$ \\
\hline Tobacco mosaic virus (TMV) & Tobamovirus & $\begin{array}{l}\text { Grasshoppers, Caterpillars } \\
\text { (occasionally) }\end{array}$ & Tobacco, tomato, Solanaceous plants & $\begin{array}{l}\text { Virus contaminated machinery, equipment, } \\
\text { farmers and smokers }[26,27]\end{array}$ \\
\hline Tomato spotted wilt virus (TSWV) & Orthotospovirus & Thrips & Peanut, pepper, tomato & $\begin{array}{l}\text { Use of infected cuttings and bulbs for } \\
\text { propagation [28] }\end{array}$ \\
\hline Rice tungro virus (RTV) & Tungrovirus & Leafhopper & Rice & $\begin{array}{l}\text { Trade of infected seeds, and transplanting infected } \\
\text { seedlings [29] }\end{array}$ \\
\hline
\end{tabular}




\section{Direct Human Intervention in Virus Spread}

There are several ways in which humans currently affect the spread of plant viral diseases. For example, the exchange of virus contaminated material between people plays a major role in transferring the virus to uninfected plants, most often as a result of limited knowledge in viral aetiology of symptomatic plants. For instance, the initial course for the spread of both African cassava mosaic virus (ACMV) [11] and sweet potato virus disease (SPVD) [30] is the exchange of infected stem cuttings and vines, respectively. If farmers are not vigilant, purchasing plant materials (i.e., seeds and tissues for vegetative propagation) from uncertified seed networks can increase the risk of global dissemination of plant virus diseases [31]. The effects are the same with the use of infected plant material for grafting, budding, and transplanting [17].

Another common way in which some viruses spread within crop fields is due to poor agricultural practices, such as the usage of unsterilised tools, not clearing plant debris, and even the continuous use of clothes and shoes that have been in the contaminated field [30,32]. No-till farming is a technique with several benefits to agriculture. However, not removing plant material from one season to another in contaminated fields can spread the virus to new plants and increase its accumulation [30]. Tobacco mosaic virus (TMV) is the typical case where the spread of the disease benefits from continuous cropping system, as it can survive or hibernate in crop debris, soil and other perennial hosts. In addition, these viruses can transmit within the field through mechanical wounds caused by contaminated tools, clothes, and footwear [26]. Interestingly, TMV is also capable of spreading via tobacco products (i.e., air-cured tobacco), where smokers rolling their cigarettes can transmit the virus with their contaminated hands [27].

Some plant diseases rely heavily on insect vectors for the transmission of the virus to a healthy plant. Tomato yellow leaf curl disease is one such case where the disease spreads by the feeding of whitefly vector carrying tomato yellow leaf curl virus (TYLCV) [7]. In this specific example, the insect-mediated viral spread is limited by the flight range of the whiteflies [33]. However, long-distance movement of insect-infested material/commodities by humans have tremendous consequences to how far the insect vector, and therefore the disease, can spread. Indeed, accidental import/export of insect vector-contaminated materials are identified as a major cause of plant virus outbreaks [12].

\section{Virus Spread Coupled with Climate Change}

The successful emergence and spread of plant viruses, and that of their vectors, are also indirectly influenced by the behaviour of mankind. Global climate change linked to human activities has increased global temperature and $\mathrm{CO}_{2}$ concentrations, leading to altered rainfall patterns, recurrent extreme weather events, as well as variations in wind velocity and direction $[3,34,35]$. Such changes have a range of impacts on the host plants, the virus, and their vectors. While some of these events can be beneficial for the plant to fight against infections, an abrupt change in the climatic conditions can also be especially helpful for the dissemination of viral diseases [36]. For example, elevated temperatures have been shown to enhance small RNA mediated defence against ACMV and cymbidium ringspot virus in Nicotiana benthamiana [37,38]; however, it also increases the contact transmission, the rate of virus multiplication and systemic movement of the virus within the plant [39]. In addition, higher temperatures are favourable for insects as vectors due to the increase in numbers of winged aphid morphs [40], shorter adult-to-adult generation time [41] and increased flight activity [42]. Moreover, alterations in wind speed and direction can affect how viruliferous vectors disseminate over long distances, affecting their distribution [39].

\section{Challenges in Mitigating Plant Viral Diseases}

Undoubtedly, lifestyle and reluctance to heed science-based information, at both an individual and societal level, have been major reasons contributing to the current COVID-19 pandemic. Modern people are accustomed to frequent domestic and international travel, large gatherings such as sporting events 
and concerts, all of which have played a central role in how fast and far the virus has spread. Similarly, the transmission of exotic plant viruses across local and international borders has been aggravated along with increased global trades of food and agriculture products. In addition, food items infected with viruses can easily travel across borders with the world's population travelling more often and further. Overall, trade-in plants, plant products, and the movement of people are accountable for the $71 \%$ of factors known as routes of emerging plant viral diseases, while $16 \%$ is due to change in the vector populations [43]. A few examples of viruses intercepted at Australian and New Zealand quarantine stations, where strict quarantine measurements are in place, are peanut stripe virus $G$, apple stem grooving virus, grapevine virus B and sweet potato virus G [43].

The COVID-19 pandemic has shown us the importance of containment measures, such as self-isolation and quarantine, in halting the spread of the disease [44]. The same strategy can also be applied to combat the spread of plant viruses. Indeed, the spread of banana bunchy top virus, potato leafroll virus, sugarcane mosaic virus and plum pox virus have been controlled using effective containment programmes [43] (Figure 1). However, such approaches are limited to situations where there are reliable diagnostics, appropriate infrastructure and community adherence to regulatory protocols. This method is heavily dependent on the commitment and actions of local and federal governments, as well as individuals, which is not always the case. It seems unlikely that the extreme actions leading to changes in our lifestyle, as seen for the COVID-19 crisis, can be easily implemented for fighting against plant viruses.

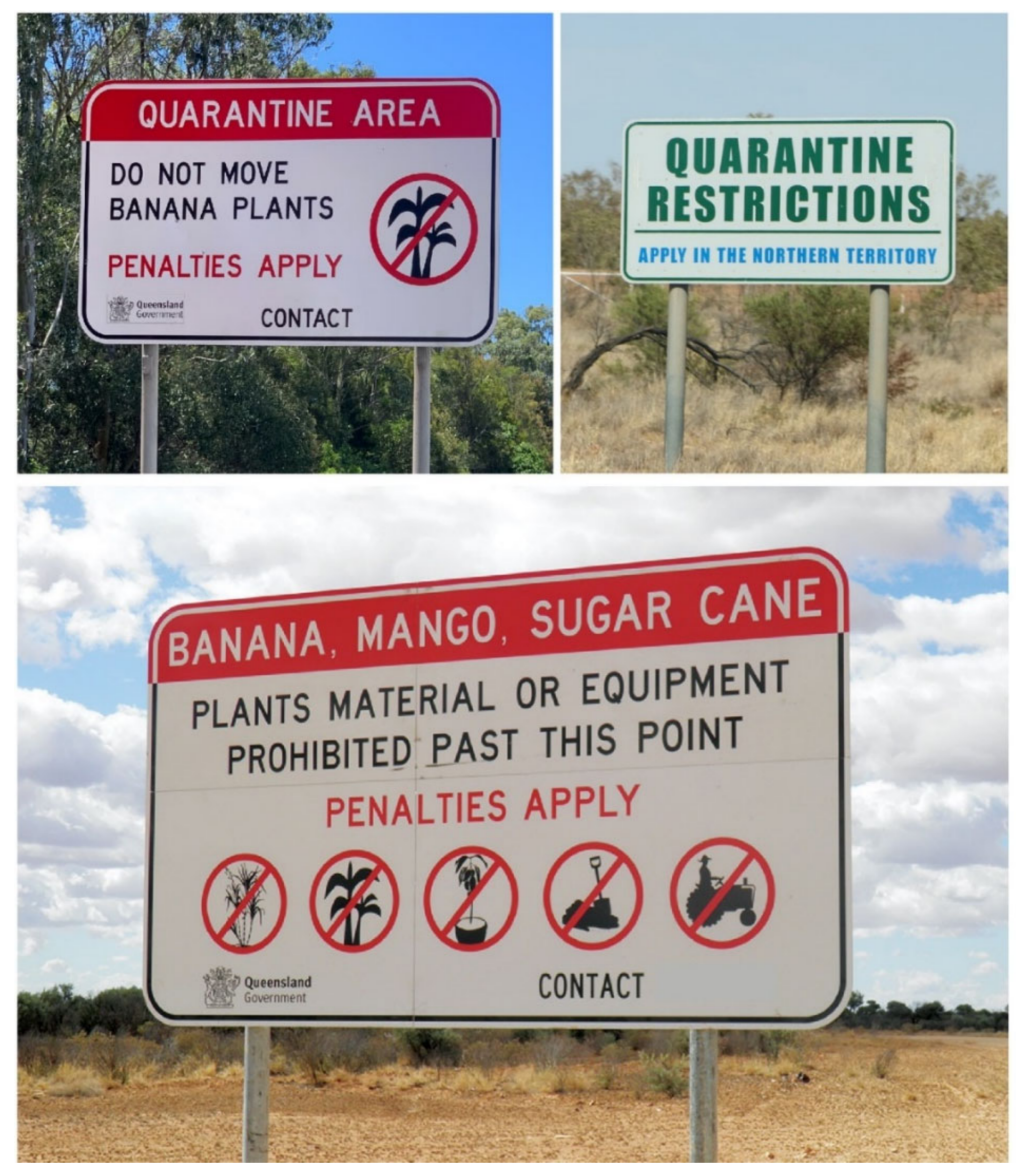

Figure 1. Containment measures as a strategy to mitigate the spread of plant viral diseases. Some countries such as Australia have strong policies to halt the spread of plant diseases, including viral ones, based on confinement and limitation on the movement of plant material and equipment. Image credit (bottom picture): Biosecurity Queensland. 


\section{Conclusions}

Ultimately, unless the threat of virus infection of food crops is perceived to be of sufficient impact (as may one day be the case due to the escalating world population and reducing areas of fertile arable land), changing human behaviour in order to minimise crop losses seems less likely to be achieved than the development of crops with new sources of virus or vector resistance. To finish on an optimistic note: never before has humanity possessed such extensive genomic information and insights about crops, their wild relatives, their pathogens and their pests; nor has it possessed such powerful molecular and genetic technologies for accelerated breeding and synthetic biology. It is probably with this information and these tools that resilient crops can be developed to increase sustainable food supplies to such a level that they offset the damages wrought by Homo sapiens, the superspreader of plant virus diseases.

Author Contributions: B.R., S.H., P.M.W. and F.F.d.F. conceived, designed, and wrote the manuscript. All authors have read and agreed to the published version of the manuscript.

Funding: This work was funded by the Australian Research Council (ARC), grant number FL160100155 and DP170103960.

Acknowledgments: We would like to thank Biosecurity Queensland and Dawit Kidanemariam (QUT) for kindly providing images used in Figure 1.

Conflicts of Interest: The authors declare no conflict of interest.

\section{References}

1. COVID-19 Dashboard by the Center for Systems Science and Engineering (CSSE) at Johns Hopkins University (JHU). Available online: https://coronavirus.jhu.edu/map.html (accessed on 18 November 2020).

2. Makkouk, K.M. Plant Pathogens which Threaten Food Security: Viruses of Chickpea and Other Cool Season Legumes in West Asia and North Africa. Food Secur. 2020, 12, 495-502. [CrossRef]

3. Jones, R.A.; Naidu, R.A. Global dimensions of plant virus diseases: Current status and future perspectives. Annu. Rev. Virol. 2019, 6, 387-409. [CrossRef] [PubMed]

4. Prasad, A.; Sharma, N.; Hari-Gowthem, G.; Muthamilarasan, M.; Prasad, M. Tomato Yellow Leaf Curl Virus: Impact, Challenges, and Management. Trends Plant Sci. 2020, 25, 897-911. [CrossRef] [PubMed]

5. Sevik, M.A.; Arli-Sokmen, M. Estimation of the effect of Tomato spotted wilt virus (TSWV) infection on some yield components of tomato. Phytoparasitica 2012, 40, 87-93. [CrossRef]

6. Rybicki, E.P. A Top Ten list for economically important plant viruses. Arch. Virol. 2015, 160, 17-20. [CrossRef] [PubMed]

7. Péréfarres, F.; Thierry, M.; Becker, N.; Lefeuvre, P.; Reynaud, B.; Delatte, H.; Lett, J.-M. Biological invasions of geminiviruses: Case study of TYLCV and Bemisia tabaci in Reunion Island. Viruses 2012, 4, 3665-3688. [CrossRef]

8. Choi, S.; Lee, J.-H.; Kang, W.-H.; Kim, J.; Huy, H.N.; Park, S.-W.; Son, E.-H.; Kwon, J.-K.; Kang, B.-C. Identification of Cucumber mosaic resistance 2 (cmr2) That Confers Resistance to a New Cucumber mosaic virus Isolate P1 (CMV-P1) in Pepper (Capsicum spp.). Front. Plant Sci. 2018, 9, 1106. [CrossRef]

9. Watanabe, S.; Greenwell, A.M.; Bressan, A. Localization, concentration, and transmission efficiency of Banana bunchy top virus in four asexual lineages of Pentalonia aphids. Viruses 2013, 5, 758-776. [CrossRef]

10. Lockhart, B. Diseases of Banana, Abacá and Enset; Banana Streak Virus: 263-274 (en); Jones, D.R., Ed.; CABI Publishing: Wallingford, UK, 1999.

11. Eni, A.O.; Efekemo, O.P.; Onile-ere, O.A.; Pita, J.S. South West and North Central Nigeria: Assessment of cassava mosaic disease and field status of African cassava mosaic virus and East African cassava mosaic virus. Ann. Appl. Biol. 2020,1-14. [CrossRef]

12. Caciagli, P. Survival of Whiteflies during Long-Distance Transportation of Agricultural Products and Plants. In Tomato Yellow Leaf Curl Virus Disease: Management, Molecular Biology, Breeding for Resistance; Czosnek, H., Ed.; Springer: Dordrecht, The Netherlands, 2007; pp. 57-63.

13. Bak, A.; Emerson, J.B. Cauliflower mosaic virus (CaMV) biology, management, and relevance to GM plant detection for sustainable organic agriculture. Front. Sustain. Food Syst. 2020, 4, 21. [CrossRef] 
14. Cauliflower Mosaic Virus (Cauliflower Mosaic). Available online: https://www.cabi.org/isc/datasheet/15099 (accessed on 25 October 2020).

15. Ali, A.; Kobayashi, M. Seed transmission of Cucumber mosaic virus in pepper. J. Virol. Methods 2010, 163, 234-237. [CrossRef] [PubMed]

16. Bacsó, R.; Künstler, A.; Király, L. Tobacco necrosis virus replication and spread in Arabidopsis thaliana ecotype Columbia: A potential system for studying plant defense reactions to symptomless virus infections. Acta Physiol. Plant. 2016, 38, 139. [CrossRef]

17. García, J.A.; Glasa, M.; Cambra, M.; Candresse, T. Plum pox virus and sharka: A model potyvirus and a major disease. Mol. Plant Pathol. 2014, 15, 226-241. [CrossRef] [PubMed]

18. Sigvald, R. Relationship between aphid occurrence and spread of potato virus $\mathrm{Y}^{\circ}\left(\mathrm{PVY}^{\circ}\right)$ in field experiments in southern Sweden. J. Appl. Entomol. 1989, 108, 35-43. [CrossRef]

19. Potato Virus Y (Potato Mottle). Available online: https://www.cabi.org/ISC/datasheet/43762 (accessed on 25 October 2020).

20. Maize Dwarf Mosaic Virus (Dwarf Mosaic of Maize). Available online: https://www.cabi.org/isc/datasheet/ 8157 (accessed on 26 October 2020).

21. Maina, S.; Barbetti, M.J.; Edwards, O.R.; de Almeida, L.; Ximenes, A.; Jones, R.A. Sweet potato feathery mottle virus and Sweet potato virus $C$ from East Timorese and Australian Sweetpotato: Biological and molecular properties, and Biosecurity Implications. Plant Dis. 2018, 102, 589-599. [CrossRef]

22. Gal-On, A. Zucchini yellow mosaic virus: Insect transmission and pathogenicity-The tails of two proteins. Mol. Plant Pathol. 2007, 8, 139-150. [CrossRef]

23. Srisink, S.; Taylor, P.; Stringer, J.; Teakle, D. An abrasive pad rubbing method for inoculating sugarcane with sugarcane mosaic virus. Aust. J. Agric. Res. 1994, 45, 625-631. [CrossRef]

24. Kouassi, N.; N'guessan, P.; Albar, L.; Fauquet, C.; Brugidou, C. Distribution and characterization of Rice yellow mottle virus: A threat to African farmers. Plant Dis. 2005, 89, 124-133. [CrossRef]

25. Abo, M.; Alegbejo, M.; Sy, A.; Misari, S. An overview of the mode of transmission, host plants and methods of detection of rice yellow mottle virus. J. Sustain. Agric. 2000, 17, 19-36. [CrossRef]

26. McDaniel, L.; Maratos, M.; Farabaugh, J. Infection of plants by tobacco mosaic virus. Am. Biol. Teach. 1998, 60, 434-439. [CrossRef]

27. Balique, F.; Colson, P.; Raoult, D. Tobacco mosaic virus in cigarettes and saliva of smokers. J. Clin. Virol. 2012, 55, 374-376. [CrossRef] [PubMed]

28. Department of Agriculture and Fisheries, Queensland Government. Spotted Wilt and Related Viruses. Available online: https://www.daf.qld.gov.au/business-priorities/agriculture/plants/fruit-vegetable/diseasesdisorders/spotted-wilt-viruses (accessed on 1 November 2020).

29. Azzam, O.; Chancellor, T.C. The biology, epidemiology, and management of rice tungro disease in Asia. Plant Dis. 2002, 86, 88-100. [CrossRef] [PubMed]

30. Wokorach, G.; Edema, H.; Echodu, R. Sweetpotato seed exchange systems and knowledge on sweetpotato viral diseases among local farmers in Acholi Sub Region-Northern Uganda. Afr. J. Agric. Res. 2018, 13, $2551-2562$.

31. Tokunaga, H.; Anh, N.H.; Dong, N.V.; Ham, L.H.; Hanh, N.T.; Hung, N.; Ishitani, M.; Tuan, L.N.; Utsumi, Y.; $\mathrm{Vu}, \mathrm{N}$.A. An efficient method of propagating cassava plants using aeroponic culture. J. Crop Improv. 2020, 34, 64-83. [CrossRef]

32. Broadbent, L. Epidemiology and control of tomato mosaic virus. Annu. Rev. Phytopathol. 1976, 14, 75-96. [CrossRef]

33. Capinera, J. Order Homoptera-aphids, leaf-and planthoppers, psyllids and whiteflies. In Handbook of Vegetable Pests, 1st ed.; Academic Press: San Diego, CA, USA, 2001; pp. 279-282.

34. Canto, T.; Aranda, M.A.; Fereres, A. Climate change effects on physiology and population processes of hosts and vectors that influence the spread of hemipteran-borne plant viruses. Glob. Chang. Biol. 2009, 15, 1884-1894. [CrossRef]

35. Cook, J.; Nuccitelli, D.; Green, S.A.; Richardson, M.; Winkler, B.; Painting, R.; Way, R.; Jacobs, P.; Skuce, A. Quantifying the consensus on anthropogenic global warming in the scientific literature. Environ. Res. Lett. 2013, 8, 024024. [CrossRef] 
36. Krishnareddy, M. Impact of climate change on insect vectors and vector-borne plant viruses and phytoplasma. In Climate-Resilient Horticulture: Adaptation and Mitigation Strategies; Springer: Berlin/Heidelberg, Germany, 2013; pp. 255-277.

37. Chellappan, P.; Vanitharani, R.; Ogbe, F.; Fauquet, C.M. Effect of temperature on geminivirus-induced RNA silencing in plants. Plant Physiol. 2005, 138, 1828-1841. [CrossRef]

38. Szittya, G.; Silhavy, D.; Molnár, A.; Havelda, Z.; Lovas, Á.; Lakatos, L.; Bánfalvi, Z.; Burgyán, J. Low temperature inhibits RNA silencing-mediated defence by the control of siRNA generation. Embo J. 2003, 22, 633-640. [CrossRef]

39. Jones, R.A.; Barbetti, M.J. Influence of climate change on plant disease infections and epidemics caused by viruses and bacteria. Plant Sci. Rev. 2012, 22, 1-31. [CrossRef]

40. Diaz, B.M.; Fereres, A. Life table and population parameters of Nasonovia ribisnigri (Homoptera: Aphididae) at different constant temperatures. Environ. Entomol. 2005, 34, 527-534. [CrossRef]

41. Muñiz, M.; Nombela, G. Differential variation in development of the B-and Q-biotypes of Bemisia tabaci (Homoptera: Aleyrodidae) on sweet pepper at constant temperatures. Environ. Entomol. 2001, 30, 720-727. [CrossRef]

42. Walters, K.; Dixon, A. The effect of temperature and wind on the flight activity of cereal aphids. Ann. Appl. Biol. 1984, 104, 17-26. [CrossRef]

43. Rodoni, B. The role of plant biosecurity in preventing and controlling emerging plant virus disease epidemics. Virus Res. 2009, 141, 150-157. [CrossRef] [PubMed]

44. Bedford, J.; Enria, D.; Giesecke, J.; Heymann, D.L.; Ihekweazu, C.; Kobinger, G.; Lane, H.C.; Memish, Z.; Oh, M.-D.; Schuchat, A. COVID-19: Towards controlling of a pandemic. Lancet 2020, 395, 1015-1018. [CrossRef]

Publisher's Note: MDPI stays neutral with regard to jurisdictional claims in published maps and institutional affiliations. 